\title{
Pengaruh Pelayanan SDM Terhadap Tingkat Kepuasan Pasien di Pelayanan Rawat Jalan RS X Jambi (Analisis Perbandingan Pasien Umum dan BPJS)
}

\author{
Ririn Noviyanti Putri ${ }^{1}$ \\ Mahasiswa Pascasarjana, Fakultas Kesehatan Masyarakat, Universitas Sriwijaya ${ }^{1}$ \\ Email : ririnnoviyanti95@gmail.com
}

\begin{abstract}
Health services require hospitals to provide quality services in accordance with the needs and desires of patients with reference to the code of ethics profession. Hospital demand in providing good service quality can improve the degree of patient satisfaction. Patient satisfaction is a common problem that often occurs in the hospital. This study aims to determine the effect of human resources service on patient satisfaction and see the ratio of the level of satisfaction between general patients and BPJS. This research is a comparative and with cross sectional approach. The sample in this study were general patients and BPJS who treated in outpatient installation as 108 respondents using chi-square statistical test and $T$ test. The results showed that there were eight variables related to patient satisfaction level, namely educational level $(p=0,0001)$, job status $(p=0.0001)$, membership status $(p=0,001)$, Service of human resources $(p=0.0001)$, Service procedures $(p=0.0001)$, Service of pharmacy $(p=0.0001)$, Comfort $(p=0,012)$, And patient relationship with hospital staff $(p=0,0001)$ and there was difference of satisfaction level between general patient and BPJS $(p=0.0001)$. Human resources services affect the level of patient satisfaction and there is difference of satisfaction level between general patient and BPJS. Suggestions for hospitals to continuously evaluate services by implementing the Plan Do Check Act (PDCA) cycle, so that the shortcomings that occur during the service process can continue to be minimized.
\end{abstract}

Keywords: Hospital; patient satisfaction; Social Security Administrator

\section{PENDAHULUAN}

Pelayanan kesehatan merupakan suatu kebutuhan setiap warga negara, oleh karena itu pemerintah menghasilkan suatu program Jaminan Kesehatan Nasional (JKN) yang diselenggarakan oleh Badan Penyelenggara Jaminan Sosial (BPJS) dengan tujuan untuk dapat meningkatkan pelayanan kesehatan secara menyeluruh (UU Nomor 40 tahun 2004). Badan Penyelenggara Jaminan Sosial melalui program JKN telah diselenggarakan sejak tanggal 1 januari 2014 yang bersifat mandatory bagi seluruh masyarakat Indonesia yang bertujuan untuk memberikan jaminan kesehatan yang menyeluruh untuk semua masyarakat di Indonesia agar dapat hidup secara sehat, produktif dan sejahtera (UU Nomor 24 tahun 2011).
Jumlah peserta BPJS kesehatan secara nasional adalah sebanyak 170.213.981 jiwa/peserta yang terdata pada tahun 2016. Menurut Peraturan BPJS nomor 4 (2014), peserta BPJS kesehatan terbagi dua yang pertama adalah masyarakat golongan fakir miskin atau tidak mampu yang preminya akan ditanggung oleh pemerintah disebut dengan peserta Penerima Bantuan Iuran (PBI) dan kedua adalah peserta Non PBI terdiri dari Peserta Penerima Upah (PPU), Peserta Bukan Penerima Upah (PBPU) dan Bukan Pekerja yang preminya ditanggung sendiri ataupun kolektif ke BPJS Kesehatan.

Awal pelaksanaan program JKN banyak mengalami beberapa kendala antara lain yaitu penduduk masih ada yang belum terdaftar sebagai peserta, distribusi pelayanan kesehatan masih belum merata, 
kualitas pelayanan kesehatan yang bervariasi, serta pelayanan kesehatan masih belum optimal (Peraturan BPJS Kesehatan No 1, 2014). Permasalahan yang ditemukan oleh Dewan Jaminan Sosial Nasional (DJSN) yaitu masih terdapatnya banyak keluhan dari masyarakat tentang sistem pelayanan yang ada, karena masyarakat tidak mengerti dan paham mengenai teknis pelayanan yang sesuai (Saputra, 2015).

Tuntutan rumah sakit dalam memberikan kualitas pelayanan yang baik dapat meningkatkan derajat kepuasan pasien. Keterlambatan dalam memberikan pelayanan, lamanya prosedur pelayanan, keterbatasan suatu obat dan peralatan ketersedian sarana serta ketertiban dan kebersihan rumah sakit yang tidak memadai merupakan suatu pengalaman dari ketidakpuasan pasien yang paling sering dikemukakan (Muninjaya, 2012). Kepuasan pasien adalah perasaan pasien yang diterima dari hasil kinerja layanan kesehatan yang dirasakan pasien dirasakan pasien dalam pelayanannya serta membandingkan dengan apa yang di harapkan (Pohan, 2012). Kualitas pelayanan merupakan suatu bentuk penilaian komsumen (pasien) terhadap tingkat pelayanan yang diterima dengan tingkat pelayanan yang diharapkan. Pelayanan kesehatan yang bermutu merupakan salah satu faktor yang berperan penting dalam mencapai kepuasan pasien. Kepuasan pasien dapat dipengaruhi oleh beberapa faktor penting seperti kenyamanan, hubungan pasien dengan staf RS, kompetensi dan biaya (Sabarguna, 2004). Pengukuran kepuasan pasien sangat diperlukan karena merupakan elemen penting dalam menyediakan pelayanan yang lebih baik, efisien dan lebih efektif (Pohan, 2007).

RS X Jambi adalah rumah sakit type B. RS X juga merupakan unit pelayanan rujukan yang harus menyediakan pelayanan prima yang bermutu sehingga pasien dan keluarga pasien dapat menikmati suatu sistem pelayanan yang memberikan tingkat kepuasan sesuai standar yang ada. Rumah sakit ini memiliki 4 pelayanan, yaitu rawat IGD, rawat jalan, rawat inap serta pelayanan penunjang. Pada layanan rawat jalan terdapat 13 poliklinik dengan total dokter yang tersedia di rumah sakit ini adalah 134 dokter dan jumlah tenaga perawat sebanyak 398 orang. Jumlah kunjungan pasien poliklinik di rumah sakit tersebut mengalami penurunan, jumlah pasien rawat jalan pada tahun 2016 yaitu 20,557 orang/tahun sedangkan pada tahun 2015 sebesar 41,119 orang/tahun.

Berdasarkan hasil observasi awal oleh peneliti di RS X Jambi pada instalasi rawat jalan, pasien banyak mengeluh akan waktu tunggu pelayanan yang sangat lama $\geq 60$ menit akibat kelalaian petugas dan sedikitnya petugas yang jaga serta kurangnya sarana \& prasarana seperti tempat duduk untuk menunggu antrian. Selain itu, berdasarkan hasil penyebaran kuesioner kepada pasien di instansi rawat jalan sebanyak $60 \%$ menyatakan keluhan terhadap pelayanan SDM dan prosedur pelayanan. Secara umum masalah yang sering dihadapi oleh rumah sakit yaitu dalam memberikan pelayanan belum sesuai dengan harapan pengguna jasa, yang mana dalam membarikan pelayanan yang baik merupakan salah satu tugas dari pelayanan SDM di rumah sakit itu sendiri.

Pelayanan yang berkualitas merupakan suatu tuntutan yang harus dipenuhi oleh rumah sakit, karena rumah sakit merupakan organisasi yang menjual jasa. Apabila pasien tidak merasa puas dengan pelayanan yang diberikan maka pasien cenderung mengambil keputusan untuk tidak melakukan kunjungan ke rumah sakit tersebut. Tujuan dalam penelitian ini adalah melihat pengaruh pelayanan SDM, dan perbandingan tingkat kepuasan antara kepuasan pasien umum dan BPJS.

\section{METODE PENELITIAN}


Penelitian ini untuk mengetahui pengaruh pelayanan SDM terhadap tingkat kepuasan pasien dan perbedaan tingkat kepuasan antara pasien umum dan BPJS terhadap pelayanan rawat jalan di RSUD X. Penelitian ini merupakan jenis penelitian kuantitatif menggunakan metode analitik yang bersifat komparatif dengan pendekatan cross sectional. Pada penelitian ini variabel independennya yaitu pelayanan SDM sedangkan tingkat kepuasan pasien umum dan BPJS merupakan variabel dependen. Sampel pada penelitian ini adalah pasien Umum dan BPJS yang berobat di instalasi rawat jalan sebanyak 108 responden yang dipilih dengan simple random sampling. Analisis data penelitian ini menggunakan analisis univariat, analisis bivariat dengan uji chi-square dan analisis perbandingan dengan uji $\mathrm{T}$.

\section{HASIL PENELITIAN}

Tabel 1. Distribusi Frekuensi Responden Rawat Jalan di RS X Jambi

\begin{tabular}{lll}
\hline Variabel & N & \% \\
\hline Jenis kelamin & & \\
Laki-Laki & 48 & 44,4 \\
Perempuan & 60 & 55,6 \\
Umur & & \\
$20-29$ th & 21 & 19,4 \\
$30-39$ th & 44 & 40,7 \\
$40-49$ th & 25 & 23,1 \\
$\geq 50$ th & 18 & 16,7 \\
Pendidikan & & \\
Tinggi & 52 & 48,1 \\
Rendah & 56 & 51,9 \\
Pekerjaan & & \\
Tidak Bekerja & 34 & 31,5 \\
Bekerja & 74 & 68,5 \\
Kepesertaan & & \\
BPJS & 58 & 53,7 \\
Umum & 50 & 46,3 \\
Pelayanan SDM & & \\
Buruk & 37 & 34,3 \\
Baik & 71 & 65,7 \\
Tingkat Kepuasan & & \\
Tidak Puas & & 37 \\
Puas & 40 & 63 \\
\hline
\end{tabular}

Hasil analisis univariat menunjukkan bahwa sebagian besar responden pada penelitian ini adalah perempuan yakni sebanyak 60 orang $(55,6 \%)$, berumur 30 39 tahun sebanyak 44 orang $(40,7 \%)$, berpendidikan rendah sebanyak 56 orang $(51,9 \%)$, berstatus bekerja sebanyak 74 orang $(68,5 \%)$, berstatus peserta BPJS sebanyak 58 orang $(53,7 \%)$ dan sebagian besar responden berpersepsi baik terhadap pelayanan SDM $(65,7 \%)$, serta mayoritas responden merasa puas terhadap pelayanan yang diberikan oleh rumah sakit yakni sebanyak 68 orang $(63 \%)$. Setelah melakukan analisis univariat, langkah selanjutnya adalah analisis bivariat. Hasil analisis bivariat yang didapatkan adalah sebagai berikut: 
Tabel 2. Hasil Analisis Bivariat Kepuasan Pasien Rawat Jalan di RS X Jambi

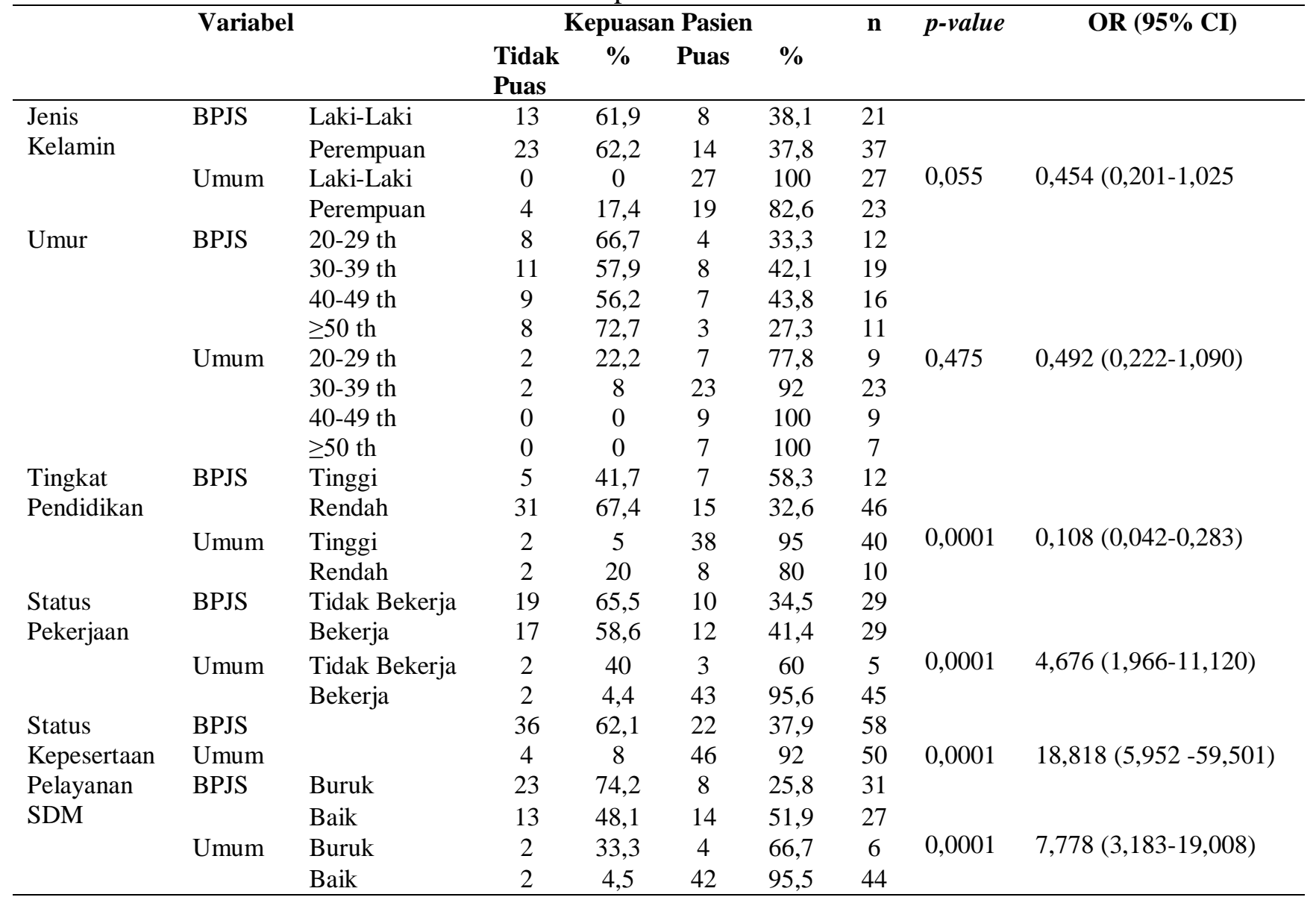

Hasil analisis bivariat menunjukkan bahwa terdapat beberapa variabel yang berhubungan dengan tingkat kepuasan pasien yaitu tingkat pendidikan $(\mathrm{OR}=0,108 ; \quad 95 \% \mathrm{CI}=0,042-0,283$; $p=0,0001)$, faktor status pekerjaan (OR=4,676; $\quad 95 \% \mathrm{CI}=1,966-11,120$; $p=0,0001)$ dan faktor status kepesertaan (OR=18,818; $\quad 95 \% \mathrm{CI}=5,952-59,501$; $p=0,0001)$, faktor pelayanan SDM (OR=7,778; $\quad 95 \% \mathrm{CI}=3,183-19,008$; $p=0,0001)$. Setelah melakukan analisis bivariat, langkah selanjutnya adalah analisis perbandingan menggunakan uji T. Sebelum melakukan uji $\mathrm{T}$, data yang ada harus melakukan uji normalitas menggunakan metode kolmogorovsmirnov. Hasil uji normalitas menujukkan bahwa nilai p $0,0001<$ apha $(0,05)$, maka data tersebut berdistribusi tidak normal. Jika data tidak terdistribusi secara normal, maka pengujian Independent sampel t-test dengan menggunakan uji Mann Whitney.

Tabel 3.

Uji Mann Whitney Data Kepuasan Pasien Rawat Jalan di RS X Jambi

\begin{tabular}{cccc}
\hline Pasien & n & Mean & p-value \\
\hline Umum & 50 & 70,18 & 0,0001 \\
BPJS & 58 & 40,98 & \\
\hline
\end{tabular}


Hasil analisis perbandingan menggunakan uji Mann Whitney menunjukkan bahwa nilai $\mathrm{p}=<0.0001$ ( $p$ value $<$ alpha 0,05$)$. Hal ini artinya bahwa terdapat perbedaan kepuasan pasien umum dan BPJS terhadap pelayanan rawat jalan di RS X Jambi dengan rerata skor tingkat kepuasan pasien umum 70,18 lebih tinggi dibandingkan dengan pasien BPJS sebesar 40,98.

\section{PEMBAHASAN}

Rumah sakit merupakan suatu unit
pelayanan menyelenggarakan pelayanan kesehatan perorangan secara merata yang terdiri dari pelayanan rawat inap, rawat jalan, dan instalasi gawat darurat (UU RI No 44, 2009). Rumah sakit dituntut untuk memberikan kualitas pelayanan yang baik dapat meningkatkan derajat kepuasan pasien. Kepuasan pasien adalah perasaan pasien yang diterima dari hasil kinerja layanan kesehatan yang dirasakan pasien dirasakan pasien dalam pelayanannya serta membandingkan dengan apa yang di harapkan (Pohan, 2012). Kepuasan pasien dapat dipengaruhi oleh berbagai macam faktor, salah satunya yaitu jenis kelamin, umur, tingkat pendidikan, status pekerjaan, status kepesertaan serta pelayanan SDM, hubungan pasien dengan staf RS, kompetensi, biaya (Notoatmodjo, 2011).

Pada variabel jenis kelamin menunjukkan bahwa sebagian besar pasien BPJS perempuan merasa puas terhadap pelayanan yang diberikan sebesar $62,2 \%$, sedangkan pada pasien umum sebagian besar pasien laki-laki merasa puas terhadap pelayanan yang diberikan. Hasil uji statistik di peroleh nilai p-value 0,055, yang artinya tidak terdapat hubungan antara jenis kelamin dengan tingkat kepuasan pasien. Hasil penelitian ini sejalan dengan penelitian terdahulu menyatakan bahwa laki-laki memiliki tingkat kepuasaan yang lebih tinggi dibandingkan perempuan (Mohammed, 2011). Pada penelitian ini rata-rata tingkat kepuasan pasien Umum maupun BPJS dengan jenis kelamin laki-laki dan perempuan hampir sama. Pada penelitian ini jenis kelamin laki-laki cenderung merasa puas dikarenakan laki laki menilai secara terus terang, apa adanya, dan lebih sabar serta mengikuti alur prosedur yang ada, jenis kelamin laki-laki tidak menuntut terlalu banyak dan lebih menerima pelayanan apa adanya sehingga tingkat kepuasan laki-laki lebih tinggi. Sedangkan jenis kelamin perempuan cenderung menilai kurang objektif karena lebih menggunakan perasaannya. Jenis kelamin perempuan kebanyakan tidak sabaran dalam menunggu dan tidak mau ribet dalam prosedur pelayanan sehingga menuntut pelayanan yang lebih lagi (Sitompul, 2012).

Hasil statistik pada variabel umur menjukkan bahwa nilai p-value 0,475 $(\mathrm{OR}=0,492 ; 95 \% \mathrm{CI}=0,222-1,090)$, maka dapat disimpulkan bahwa tidak terdapat hubungan antara umur dengan tingkat kepuasan pasien. Pasien BPJS dari rentang umur 20-49 tahun tingkat kepuasannya semakin meningkat dan pada umur $40-\geq 50$ tahun tingkat kepuasannya menurun, sedangkan pasien umum dari rentang umur 20- $\geq 50$ tahun merasa puas terhadap pelayanan yang diberikan. Hasil penelitian ini sejalan dengan penelitian terdahulu yang menyatakan bahwa tidak terdapat hubungan yang signifikan antara signifikan antara umur dengan tingkat kepuasan pasien (Ozzi, 2016).

Tingkat kepuasan pasien umum maupun BPJS dari umur 20 - $\geq 50$ hampir sama. Pada masa dewasa awal (20-29 tahun) tingkat kepuasan pasien rendah dikarenakan pada masa usia tersebut pasien berani mengemukakkan pendapat, sedangkan ketika memasuki usia dewasa (30-39 tahun) pasien lebih menerima saja pelayanan yang diberikan oleh pihak RS sehingga tingkat kepuasan meningkat. Pada masa lansia ( $\geq 50$ tahun) tingkat kepuasan pasien kembali menurun dikarenakan faktor usia (Ozzi, 2016). 
Pada variabel tingkat pendidikan menujukkan bahwa terdapat hubungan antara tingkat pendikan dengan kepuasan pasien dengan nilai $p$-value 0,0001 (OR=0,108; 95\%CI=0,042-0,283). Pasien BPJS maupun pasien umum yang berpendidikan tinggi cenderung merasa puas terhadap pelayanan yang diberikan. Hasil ini sejalan dengan penelitian sebelumnya yang menyatakan bahwa ada hubungan yang bermakna antara tingkat pendidikan dengan kepuasan pasien. Ungkapan suatu rasa kepuasan pada sekelompok individu dapat sama karena dapat terpengaruh oleh lingkungan dan golongan tertentu. Orang yang berpendidikan tinggi kemungkinan lebih mengerti dan lebih memahami serta mempunyai kesadaran yang lebih baik sehingga cenderung lebih merasa puas terhadap pelayanan yang diberikan dibandingan dengan orang yang berpendidikan dasar karena pengetahuan mereka yang kurang tentang masalah pelayanan kesehatan sehingga pasien tersebut tidak mengerti tentang prosedur pelayanan yang ada dan menyebabkan ketidakpuasan pasien (Neneng, 2002).

Status pekerjaan berdasarkan hasil penelitian ini menyatakan bahwa terdapat hubungan dengan kepuasan pasien. Hasil uji statistik di peroleh nilai $p$-value 0,017 $(\mathrm{OR}=2,943 ; \quad 95 \% \mathrm{CI}=1,196-7,243)$. sebagian besar pasien BPJS berstatus tidak bekerja merasa tidak puas terhadap pelayanan yang diberikan (65,5\%), sedangkan pasien umum yang bekerja merasa puas terhadap pelayanan yang diberikan $(95.6 \%)$. Hasil penelitian ini sejalan dengan penelitian terdahulu yang menggemukakan bahwa terdapat hubungan yang bermakna antara status pekerjaan dengan tingkat kepuasan pasien (Farianita, 2016).

Masyarakat yang memiliki status pekerjaan lebih baik maka tingkat kepuasannya juga lebih tinggi. Pasien BPJS yang berstatus bekerja cenderung merasa tidak puas karena sebagian besar dari pasien BPJS tersebut berstatus Non PBI dengan tingkat pekerjaan yang berbeda, yang mana mereka dituntut untuk membayar premi setiap bulannya sehingga mereka menginginkan pelayanan yang baik. Sedangkan pada pasien umum seseseorang yang bekerja memiliki tingkat kepuasan yang tinggi dikarenakan mereka memiliki pengetahuan dan pengalaman yang lebih terhadap pelayanan kesehatan dibandingkan dengan orang yang tidak bekerja (Sitompul, 2012).

Status kepesertaan merupakan salah satu variabel dalam penelitian ini yang berpengaruh terhadap kepuasan pasien. Sebagian besar pasien BPJS 62,1\% merasa tidak puas terhadap pelayanan yang diberikan, sedangkan pasien umum sebagian besar $92 \%$ merasa puas terhadap pelayanan yang diberikan. Hasil uji statistik di peroleh nilai $p$-value 0,0001 $(\mathrm{OR}=18,818 ; 95 \% \mathrm{CI}=5,952-59,501)$. Hasil ini sejalan dengan penelitian sebelumnya yang menyatakan bahwa terdapat hubungan antara status kepesertaan dengan kepuasan pasien (Ambar, 2015). Peserta BPJS merasa kurang puas dibandingkan dengan pasien umum dikarenakan pasien BPJS setiap bulannya mempunyai kewajiban untuk membayar dan cenderung untuk menuntut pelayanan yang lebih baik. Pada penelitian ini peserta BPJS cenderung merasa tidak puas karena dari 55 pasien BPJS tersebut sebagian besar sebanyak 40 orang berstatus Non PBI yang mana mereka menuntut hak atas jaminan kesehatan yang mereka miliki yang mana peserta BPJS bergolongan Non PBI berkewajiban untuk membayar premi setiap bulannya sehingga menginginkan pelayanan yang optimal (Ozzi, 2016).

Petugas kesehatan di rumah sakit dalam menyelenggarakan kegiatan kesehatan harus sesuai dengan bidang keahlian dan mematuhi standar profesi yang ada serta menghormati hak pasien tersebut (Nugroho, 2011). Hasil statistik memperoleh nilai $p$-value 0,0001 $(0 \mathrm{R}=7,778 ; \quad 95 \% \mathrm{CI}=3,183-19,008) \quad$ yang 
artinya terdapat hubungan antara pelayanan SDM dengan tingkat kepuasan pasien atau pelayanan SDM berpengaruh terhadap tingkat kepasan pasien. Sebagian besar pasien BPJS berpresepsi buruk terhadap pelayanan SDM dan $74,2 \%$ merasa tidak puas terhadap pelayanan yang diberikan. Sedangkan pasien umum sebagian besar berpresepsi baik terhadap pelayanan SDM dan 95,5\% merasa puas terhadap pelayanan yang diberikan.

Masyarakat pada dasarnya berobat untuk mendapatkan pelayanan kesehatan di rumah sakit tersebut, yang mana tenaga kesehatan yang ada dirumah sakit tersebut merupakan pegawai inti dari rumah sakit dan berkewajiban untuk memberikan pelayanan kesehatan kepada pasien. Dokter, perawat, serta petugas kesehatan lainnya akan berhubungan langsung dengan pasien yang dapat menghasilkan tingkat kepuasan pasien yang berobat di rumah sakit tersebut (Nugroho, 2011). Hasil penilaian pasien umum terhadap pelayanan SDM yang ada di rumah sakit tersebut sudah baik yang dapat dilihat dari sikap dokter, perawat, dan petugas kesehatan lainnya, kebedaradan dokter dan perawat yang hadir pada hari - hari kerja. Akan tetapi, pasien BPJS berpresepsi buruk terhadap pelayanan SDM. Pasien BPJS banyak mengeluh akan jam pelayanan, karena terkadang ada dokter yang telat hadir pada jam kerja yang telah ditentukan dikarenakan dokter harus visit ke ruangan rawat inap sehingga menyebabkan pasien menunggu lama serta pasien.

Saat pertama pasien memasuki rumah sakit untuk memperoleh pelayanan kesehatan, maka pelayanan yang pertama diperoleh adalah prosedur pelayanan. Pada tahap ini pasien sangat membutuhkan informasi tentang prosedur pelayanan, yang mana disinilah peran tugas pendaftaran (SDM) harus dapat memberikan informasi yang jelas dan mengarahkan pasien dengan tepat agar pasien mendapatkan pelayanan sesuai dengan yang diinginkan (Farianita, 2016).

Petugas kesehatan di rumah sakit tersebut dalam menyelenggarakan kegiatan kesehatan harus sesuai dengan bidang keahlian dan mematuhi standar profesi yang ada serta menghormati hak pasien tersebut. Selain itu pelayanan petugas juga berkaitan dengan hubungan antarmanusia, yaitu antara pemberi layanan dengan pasien secara langsung seperti pelayanan dari apotik rumah sakit tersebut, yang mana setelah pasien berobat, pasien mengharapkan kesembuhan yang dibantu dengan obat yang telah diresepkan oleh dokter. Apabila pelayanan SDM di apotik di rumah sakit baik, ketersedian obat cukup, petugas menjelaskan cara pakai obat dengan baik serta memperhatikan kembali resep yang dibuat oleh dokter maka dapat terciptanya kepuasan pasien serta dapat menentukan sikap dan perilaku selanjutnya terhadap pelayanan rumah sakit (Farianita, 2016).

Petugas rumah sakit (SDM) dalam bentuk dari berhubungan dengan pasien yang baik dapat berupa menghargai, menjaga rahasia, menghormati, mendengarkan keluhan, responsif, dan memberikan perhatian. Hubungan pasien dengan staf SDM rumah sakit yang baik dalam pelaksanaan pelayanan kesehatan dapat membentuk persepsi positif pasien (Bustami, 2011). Hubungan pasien dengan staf SDM rumah sakit yang kurang baik dalam suatu pelayanan dapat mengurangi kadar dimensi efektivitas dan dimensi kompetensi teknis dari layanan kesehatan yang diselenggarakan. Pengalaman menunjukkan bahwa pasien yang diberlakukan kurang baik cenderung akan mengabaikan nasihat dan tidak akan melakukan kunjungan ulang (Pohan, 2007). Sikap petugas kesehatan terhadap pasien tersebut dapat menentukan tingkat kepuasan. Apabila hubungan pasien dengan staf RS baik, petugas ramah dan sopan serta memberikan informasi yang jelas maka akan meningkatkan derajat 
kepuasan pasien serta dapat mempengaruhi mutu pelayanan rumah sakit tersebut (Sarah, 2015).

Hasil analisis perbandingan tingkat kepuasan pasien menggunakan uji Mann Whitney menunjukkan bahwa terdapat perbedaan kepuasan pasien umum dan BPJS terhadap pelayanan rawat jalan di RS $\mathrm{X}$ Jambi. Tingkat kepuasan pasien umum lebih tinggi dibandingkan tingkat kepuasan pasien BPJS. Hasil penelitian ini sejalan dengan penelitian terdahulu yang menyatakan terdapat perbedaan tingkat kepuasan antara pasien umum dan BPJS (Ozzi, 2016). Perbedaan yang dirasakan dari sebelum dan sesudah adanya program BPJS, pasien ternyata merasa dengan adanya BPJS menjadi lebih tercukupi untuk berobat, karena tidak mengeluarkan biaya lagi. Namun, ada beberapa hal yang masih mengganjal disini adalah pelayanannya yang masih lama (Octavia, 2012).

Mengukur tingkat kepuasan pasien terhadap proses pelayanan yang didapatkan pada pasien BPJS bukan hanya dari sisi medis saja, tetapi juga administrasi dimana sebelum mendapatkan pelayanan medis pasien juga mendapatkan pelayanan dari BPJS terlebih dahulu. Hal ini dapat mempengaruhi kepuasan pasien terhadap rumah sakit, karena kaitannya dengan waktu tunggu saat mendapatkan pelayanan BPJS sebelum mendapatkan pelayanan medis. Proses sistem rujukan berjenjang yang dirasakan setelah adanya BPJS, ini juga mempengaruhi kepuasan pasien terhadap BPJS sendiri (Ismawan, 2008).

Hasil penelitian menyatakan terdapat perbedaan tingkat kepuasan pasien Umum dan BPJS karena sebagian besar responden pada penelitian ini adalah pasien BPJS dan rata-rata pasien BPJS tersebut berpendidikan rendah. Pasien BPJS banyak mengeluh terhadap pelayanan SDM seperti pelayanan dari prosedur pelayanan, pelayanan apotik serta hubungan pasien dengan petugas SDM rumah sakit. Pasien BPJS banyak yang tidak mengerti dengan prosedur pelayan yang harus mereka ikuti. Selain itu, mereka juga sedikit kurang paham atas penjelasan ataupun informasi dari petugas kesehatan mengenai pelayanan ataupun diagnosa penyakit yang mereka derita. Hal tersebut berkaitan erat dengan pelayanan SDM seperti pelayanan prosedur pelayanan serta hubungan pasien dengan staf SDM rumah sakit, sedangkan pada pelayanan apotik mereka merasa bahwa tidak mendapatkan hak yang seharusnya mereka dapatkan karena stok obat BPJS yang ada di rumah sakit tersebut sering habis dan menyebabkan mereka harus menebus obat diluar apotik.

Kepuasan pasien berkaitan erat dengan pelayanan SDM yang ada serta pemasaran rumah sakit. Pasien yang puas akan merekomendasikan teman, keluarga, dan tetangga, pasien yang puas akan datang kembali untuk kontrol atau memerlukan pelayanan yang lain. Pelayanan SDM yang memuaskan akan mendapatkan pelanggan lebih banyak lagi (Octavia, 2012).

\section{SIMPULAN}

Pelayanan SDM di rumah sakit berpengaruh signifikan terhadap tingkat kepuasan pasien rawat jalan di RS X Jambi serta terdapat perbedaan tingkat kepuasan antara pasien umum dan BPJS.

\section{DAFTAR PUSTAKA}

Bustami, 2011, Penjaminan Mutu
Pelayanan Kesehatan dan
Akseptabilitasnya, Erlangga,
Jakarta.

Farianita Rafika. 2016. Faktor - Faktor yang Berhubungan dengan Kepuasan Pasien Peserta BPJS Terhadap Pelayanan Instalasi Rawat Jalan di RS TK. III BHakti Wira Tamtama Semarang. Universitas Negeri Semarang.

Imelda Sarah, Nahrisah Ezzah, 2015, Analisis Tingkat Mutu Pelayanan Rawat Inap dalam Upaya Peningkatan Kepuasan Pasien di 
RSUP Adam Malik Medan (Studi Perbandingan Antara Pasien Umum dan BPJS), Vol. 3, No. 3, Jurnal Informatika.

Ismawan, N.L. 2008. Analisis Kepuasan dan Hubungannya dengan Loyalitas Pasien Rawat Inap Di Rumah Sakit Dedi Jaya Kabupaten Brebes. Thesis : Universitas Diponegoro Semarang.

Mohammed, Shafiu, 2011, Understanding Client Satisfaction With a Health Insurance Scheme in Nigeria: Faktor and Enrollees Experiances, Jurnal BioMed.

Muninjaya, Gde. 2012. Manajemen Mutu Kesehatan. Jakarta: Penerbit Buku Kedokteran EGC.

Neneng. 2002. Kepuasan Pasien Jaminan Terhadap Pelayanan Rawat Jalan RSUD Bekasi. FKM UI. Jakarta.

Notoatmodjo, Soekidjo. 2011. Kesehatan Masyarakat Ilmu dan Seni. Jakarta: Rineka Cipta.

Nugroho, Singgih. 2011. Analisis Mutu Pelayanan Terhadap Kepuasan Pasien Umum Di Balai Pengobatan Umum Puskesmas Wonopringgo Kabupaten Pekalongan. Universitas Diponegoro. Semarang.

Octavia Ade. 2012. Analisis Kepuasan Pasien Rawat Inap Bangsal Jantung di RSUD Raden Mattaher Jambi. Vol 1 Nomor 1. ISSN 2302-4682.

Ozzi Zarra, 2016. Perbedaan Tingkat Kepuasan Pasien BPJS dan Non BPJS Pada Mutu Pelayanan Pendaftaran Rumah Sakit Pusat Angkatan Udara dr. S. Hardjolukito Bantul. Program Studi Fakultas Kesehatan Masyarakat Universitas Muhammadiyah. Surakarta.

Peraturan Badan Penyelenggara Jaminan Sosial Kesehatan No 1, 2014, Penyelenggaraan Jaminan Kesehatan, Republik Indonesia, Jakarta.
Peraturan BPJS Nomor 4 tahun 2014 tentang tata cara pendaftaran dan pembayaran peserta perorangan badan penyelenggara jaminan sosial kesehatan.

Pohan, Imbalo S. 2012. Jaminan Mutu Layanan Kesehatan. Jakarta: Penerbit Buku Kedokteran ECG.

Republik Indonesia. 2004. UndangUndang RI Nomor 40 Tahun 2004 tentang Sistem Jaminan Sosial Nasional.

Republik Indonesia. 2011. UndangUndang RI Nomor 24 Tahun 2011 tentang Badan Penyelenggara Jaminan Sosial.

Sabarguna. B, S, 2004. Pemasaran Pelayanan Rumah Sakit. Sagung Seto. Jakarta.

Saputra Maman. 2015. Program Jaminan Kesehatan Nasional dari Aspek Sumber Daya Manusia Pelaksana Pelayanan Kesehatan. Jurnal Kesehatan Masyarakat Unnes.

Sitompul, Juliani, 2012, Faktor-Faktor Yang Berhubungan Dengan Kepuasan Peserta Askes Sosial Terhadap Pelayanan Askes Center Di Rs. Depati Hamzah Pangkalpinang, Universitas Indonesia, Jakarta.

Undang-Undang Republik Indonesia No. 44, 2009, Rumah Sakit, Republik Indonesia, Jakarta. 